\title{
Konstruksi Mutu Pendidikan Melalui Literasi Keuangan Pada Pendidikan Anak Usia Dini di Magetan
}

\author{
Mukhibat, Mukhibat \\ Intitut Agama Islam Negeri Ponorogo \\ DOI: $10.31004 /$ obsesi.v4i2.412
}

Email: Mukhibat@iainponorogo.ac.id

\begin{abstract}
Abstrak
Penelitian ini bertujuan mendeskripsikan dan menganalisis peningkatan mutu pendidikan di Kelompok Kerja (POKJA) RA Poncol Magetan melalui program sedekah sampah. Penelitian ini menggunakan pendekatan kualitatif dengan pesrpektif ethnoscience, dengan berusaha memahami perspektif lokal tentang pengelolaan sampah dengan menerapkan interview etnografi untuk memperoleh sejumlah taksonomi pengetahuan lokal. Sedekah sampah telah menjadi salah satu solusi persoalan sumber pembiayaan dan lemahnya literasi keuangan, sehingga RA yang tergabung dalam POKJA RA Poncol Magetan memiliki kesiapan yang optimal dalam pelaksanaan program-program pendidikannya pada aspek perencanaan, pelaksanaan, dan evaluasi pembelajaran. Selain itu POKJA RA Poncol Magetan memiliki keberdayaan yang baik melalui keterampilan dalam menyusun arus kas yang benar dalam merencanakan, melaksanakan, dan mengevaluasi pembelajarnnya melalui sedekah sampah, dimana sedekah sampah merupakan alternatif pemecahan masalah sampah yang memadukan unsur edukasi dan pemberdayaan yang berkelanjutan.
\end{abstract}

Kata Kunci: kontruksi mutu; litarasi keuangan; RA; sedekah sampah.

\begin{abstract}
This study aims to describe and analyze the improvement of the education quality of RA Poncol Magetan Teamwork through the alms trash program. This study employed a qualitative approach with ethnoscience perspective. It tried to understand the local perspective about trash management. It was based on the ethnographic interview to obtain the taxonomy of local knowledge. Alms trash had been one of the solutions to funding and weak financial literacy problems. Thus, RA which is incorporated in RA Poncol Magetan Teamwork has the optimal readiness in the implementation of the educational program in the aspects of planning, implementing, and evaluating the learning process. Besides, it has good empowerment through the skills in preparing the correct cash flow in planning, implementing, and evaluating learning through alms trash, where it is an alternative solution to waste problems that combine elements of education and sustainable empowerment.
\end{abstract}

Keywords: quality construction; financial literacy; $R A$, alms trash.

Copyright (c) 2020 Mukhibat, Mukhibat

$\triangle$ Corresponding author :

Email Address : mukhibat@iainponorogo.ac.id (Ponorogo Jawa Timur)

Received 4 January 2020, Accepted 16 january 2020, Published 18 January 2020 


\section{PENDAHULUAN}

Sebagaimana diketehui bahwa salah satu faktor utama penentu pendidikan adalah terkait dengan masalah biaya. Kajian tentang pembiayaan pendidikan, selalu diiringi masalahyang muncul yaitu, baik sumber-sumber pembiayaan, minimnya anggaran, penyimpangan dan alokasi dana yang belum memadai (Sonedi, Jamalie, \& Majeri, 2017). Pembiayaan pendidikan dan tidak standarnya sarana dan prasarana pendidikan merupakan dari sekian masalah yang dihadapi oleh pendidikan Islam.Tanggung jawab pembiayaan pendidikan sebenarnya telah diatur dalam UU No. 20 tahun 2003 bab XIII pasal 46 ayat 1 tentang tanggung jawab pendanaan disebutkan bahwa: "Pendanaan pendidikan menjadi tanggung jawab bersama antaraPemerintah, Pemerintah Daerah dan Masyarakat (Indonesia, 2003)". Khusus lembaga pendidikan Islam (RA, MI, MTs, MA, PTKI), Kementerian yang paling otoritatif dalam melakukan penataan regulasi, rekognisi, dan fasilitasi atas layananlayanan pendidikan adalah Kemenag RI.

Kemampuan pemerintah dalam pembiayaan pendidikan menjadi kendala besar dalam penyelenggaraan pendidikan yang bermutu, tidak terkecuali madrasah swasta termasuk RA-RA (Rindaningsih, 2012) yang tergabung dalam Kelompok Kerja RA (POKJA RA) Poncol Magetan. Problem pembiayaan POKJA RA Poncol ((RA Putra Harapan Janggan, RA Muslimat Alastuwo, RA Darul Ulum Poncol, dan RA Gonggang), tersebut semakin memprihatinkan dengan rendahnya kemampuan literasi keuangan dari pengelolanya. Hasil observasi menunjukkan bahwa pengelolaan pembiayaan pendidikan yang bersumber dari orang tua, belum dikelola dengan manajemen yang baik, mulai dari proses perencanaan, pelaksanaan dan dalam pengawasannya.

Terhadap persoalan di atas, (Firdaus \& Ariyanti, 2004) mengingatkan kepada lembaga pendidikan akan pentingnya tata kelola pembiayaan dengan strategi kemitraan dengan masyarakat lingkungan sekolah. Melihat penting dan strategisnya kemitraan dan kerjasama dengan masyarakat dalam meningkatkan mutu pendidikan, POKJA RA Poncol sejak tahun 2018 telah melakukan Gerakan Sedekah Sampah (GESHOSA) bekerja sama dengan wali murid dan masyarakat. Hal ini didasarkan pada pemahaman bahwa pengelolaan sampah yang benar akanmempunyai nilai ekonomis sebagai sumber pembiayaan pendidikan. Selain itu, meningkatkan volume sampah, ternyata belum diiringi dengan kesadaran masyarakat dalam mengelola sampah dengan baik. Undang-Undang Nomor 18 tahun 2008 tentang Pengelolaan Sampah beserta Peraturan Pemerintah Nomor 81 Tahun 2012 mengamanatkan perlunya perubahan paradigma pengelolaan sampah dengan pendauran ulang dan pemanfaatan kembali sampah atau yang lebih dikenal dengan sebutan Reduce, Reuse dan Recycle (3R) melalui upaya-upaya cerdas, efisien dan terprogram (Maya, Haryono, \& Kholisya, 2018, p. 158). Harapan dengan 3R adalah meningkatnya kesadaran masyarakat akan kebersihanlingkungan dan membuka pandangan dan wawasan baru bagi masyarakat dalam mengelola sampah. Sampah tidak lagi dipandang sebagai barang yang tidak berguna, akan tetapi sampah dapat dijadikan suatu yang bernilai tambah (Triwardani, 2013).

Program Gerakan Sedekah Sampah (GESHOSA) yang dilakukan oleh POKJA RA Poncol merupakan bentuk penanaman pembiasaan positif dalam kehidupan pada anak sejak dini sebagai bentuk nyata berperilaku hidupn sehat dan untuk mengatasi degradasi lingkungan tersebut (Herliyati \& Suparmini, 2018) secara berkesinambungan (sustainable), yang meliputi tahap penyadaran, tahap tranformasi kemampuan, dan tahap peningkatan kemampuan intelektual dan kecakapan-keterampilan. GESHOSA selain sebagai alternatif pendidikan karakter juga sebagai bentuk telah menjadi bagian dari literasi keuangan dalam meningkatkan mutu pendidikan.Pengelolaan sampah melalui sedekah sampah ini telah menjadi alternatif pemecahan masalah sampah yangmampu memadukan unsur edukasi dan pemberdayaan, serta telah menjadi salah satu solusi sumber pembiayaan bagi lembaga pendidikan di POKJA RA Poncol Magetan. Sehingga dapat dikatakan bahwa GESHOSA telah mampu memadukan aspek pendidikan, kesehatan, dan ekonomi. 
Kajian tentang pengelolaan sampah sebenarnya telah banyak dilakukan dengan berbagai pendekatan disiplin ilmu seperti: Ilmu Lingkungan, Sosiologi, Tata Ruang Kota, Ilmu Kesehatan, dan lainnya. Namun, penelitian tentang pengelolaan sampah dengan pendekatan ilmu Manjemen Pembiayaan sepanjang pengetahuan peneliti belum ditemukan. Oleh karenanya peneliti tertarik untuk mengkaji lebih mendalam tentang literasi keuangan berbasis pada pengelolaan sampah dari perspektif manajemen pembiayaan pendidikan. Literasi keuangan dibatasi pada bagaimana tingkat kesadaran warga sekolah di POKJA RA Poncol dalam mengelola pendidikannya berdasarkan sumber-sumber pembiayaannya dari sedekah sampah.

Permasalahan sampah di Magetan terkait dengan masalah jangkauan pelayanan, dampak dari perilaku pembuangan sampah yang tidak baik, dan masalah teknis pengelolaan sampah di TPA.Permasalahan yang muncul dari masyarakat penghasil sampah adalah kurangya kesadaran masyarakat dalam mensikapi dan mengelola sampah. Masyarakat masih banyak yang membuang sampah sembarangan di sungai.Bahkan ketika sudah disediakan tempat pembuangan sampah sememtara (TPSS) di lingkungannya, masyarakat masih tidak tertib dalam waktu ataupun tempat membuang sampahnya. Konsep 3R (reduse, replace, recycle) tidak diterapkan dengan baik danperilaku membuang sampah sembarangan masih tinggi (Mulansari, 2016: 99). Fenomena tersebut menunjukkan betapa rendahnya rasa dan perilaku peduli lingkungan manusia saat ini.

Melihat berbagai fenomena di atas, POKJA RA Poncol merasa bertanggung jawab untuk menanamkan rasa peduli, empati, simpati, tanggung jawab, peka sosial dalam menjaga dan memperhatikan lingkungan serta melestarikannya. Terjadinya degradasi lingkungan merupakan bentuk permasalahan yang salah satunya karena permasalahan sampah yang mencerminkan akar dari rendahnya perilaku peduli lingkungan manusia. Maka, diperlukannya wadah dan sistem edukasi yang tepat dalam menanamkan nilai peduli lingkungan demi menjaga lingkungan dan makhluk hidup.

Program Gerakan Sedekah Sampah (GESHOSA) yang dilakukan oleh POKJA RA Poncol merupakanbentuk penanaman pembiasaan positif dalam kehidupan pada anak sejak dini sebagai bentuk nyata berperilaku hidupn sehat dan untuk mengatasi degradasi lingkungan tersebut (Herliyati, 2018) secara berkesinambungan (sustainable), yang meliputi tahap penyadaran, tahap tranformasi kemampuan, dan tahap peningkatan kemampuan intelektual dan kecakapan-keterampilan. GESHOSA selain sebagai alternatif pendidikan karakter juga sebagai bentuk telah menjadi bagian dari literasi keuangan dalam meningkatkan mutu pendidikan. Pengelolaan sampah melalui sedekah sampah ini telah menjadi alternatif pemecahan masalah sampah yangmampu memadukan unsur edukasi dan pemberdayaan, serta telahmenjadi salah satu solusi sumber pembiayaan bagi lembaga pendidikan di POKJA RA Poncol Magetan. Sehingga dapat dikatakan bahwa GESHOSA telah mampu memadukan aspek pendidikan, kesehatan, dan ekonomi.

Diharapkan melalui kajian dan penelitian ini, peneliti akan melihat secara lebih lanjut mengenai keberlangsungan pelaksanaan Program Sedekah Sampah, serta apakah program ini mampu menanamankan kebiasaan berperilaku peduli lingkungan pada siswa. Tentunya berjalannya kegiatan Sedekah Sampah tidak selamanya berjalan lancar, terdapat beberapa hambatan yang terjadi di lapangan.Antusiasme keterlibatan orang tua dan siswa dalam program tersebut juga perlu diamati sehingga ketercapaian tujuan pelaksanaan Program Sedekah Sampah ini dapat terlihat melalui perilaku yang muncul pada orang tua dan siswa.

\section{METODE PENELITIAN}

Penelitian ini menggunakan penelitian deskripstif kualitatif, yaitu penelitian yang obyek utamanya peristiwa atau fenomena dalam kehidupan sehari-hari.Data dikumpulkan dengan menggunakan metode wawancara, observasi dan dokumentasi. Analisis Data dilakukan sesuai dengan analisis model Miles dan Huberman, secara operasional teknik 
analisis tersebut dilakukan dengan beberapa tahapan reduksi data dan penarikan kesimpulan (Miles, B. M., \& Huberman, 1992: 16).

Adapun pendekatan yang digunakan dalam penelitian ini adalah dengan ethnoscience, yaitu memahami perspektif lokal dengan menerapkan interview etnografi untuk memperoleh sejumlah taksonomi pengetahuan lokal (Rosyidah, Sudarmin, \& Siadi, 2013, p. 134) khususnya tentang literasi keuangan melalui adaptasi dalam mengelola sampah sebagai alternatif sumber pendanaan pendidikan POKJA RA Poncol Magetan. Pendekatan etnosains ini didasarkan pada kenyataan bahwa POKJA RA Poncol menganggap cara penanganan sampah yang selama ini dilakukan secara turun-temurun tidak ada hubungannya sama sekali dengan kegiatan pembelajaran di sekolah. Maka penelitian ini ingin membuktikan bahwa proses penanganan sampah secara ilmiah akan mempunyai nilai ekonomi, edukasi, dan, kesehatan, yang merupakan komponen penting dalam konstruksi mutu pendidikan.Sedekah sampah sebagai bentuk literasi keuangan yang memadukan unsur edukasi, kesehatan, dan ekomoni, sebagai upaya pemberdayaan yang berkelanjutan bagi guru-guru di POKJA RA Poncol Magetan perlu dikaji dan diteliti yang bisa menjasi bentuk konstruksi mutu pada aspek perencanaan, pelaksanaan, dan evaluasi melalui literasi keuangan di POKJA RA Poncol Magetan.

\section{HASIL DAN PEMBAHASAN}

\section{Gerakan Shedekah Sampah (GESHOSA)}

Saat ini, Kabupaten Magetan memiliki 95 RA yang tersebar di 18 Kecamatan(Magetan, 2019), adapun di POKJA RA Poncol Magetan ada empat RA itu adalah: RA Putra Harapan, RA Darul Ulum, RA Al Hidayah, RA Plumpung, RA Muslimat, dengan jumlam murid 270 dengan 19 tenaga pendidikan. Empat RA tersebut tidak ada yang mendapatkan bantuan pembiayaan yang memadahi dalam melaksanakansistem perencanaan, pelaksanaan, dan evaluasi pembelajarannya. RA yang tergabung dalam POKJA RA Poncol Magetan semua pembiayaannya mengandalkan SPP dari murid yakni Rp. 25.000,- perbulan. Dana dari SPP itu digunakan untuk transportasi guru rata-rata tiap sekolah sebesar Rp. 250.000,- jadi pengeluaran dari POKJA RA Poncol Magetan Rp. 4.750.000,- sisanya sekitar Rp. 500.000,- untuk iuran IGRA dan kegiatan POKJA RA setiap sebulan sekali(Magetan, 2019).

Kondisi POKJA RA Poncol Magetan bertambah memprihatikan, ketika harus menerima perlakukan deskriminatif dari pemerintah daerah di tingkat desa, dimana lembaga pendidikan sejenis yakni PAUD/TK bisa mendapatkan bantuan dari Dana Desa (DD), sementara RA tidak mendapatkan dengan alasan bukan milik desa (wawancara, Jumini, 2019). Fakta dan data yang demikian, sangatlah berlebihan dan tidak fair kalau pemerintah menuntut pendidikan yang bermutu bagi RA. Kondisi marginal, perlakuan deskriminatif telah menyebabkan mutu pendidikan di POKJA RA Poncol Magetan semakin sulit ditingkatkan. Mutu pendidikan menjadi persoalan yang sangat rumit dan kompleks, baik yang berkaitan dengan perencanaan, pelaksanaan dan pelaporan pembiayaan pendidikan. Sementara kalau mengacu pada Standar PAUD alokasi pendanaan yang harus menjangkau bagi kegiatan yang berhubungan langsung dengan upaya peningkatan standar mutu PAUD (Jamaris, Meilanie, Dwi Utami, 2020).

Kesadaran akan pentingnya kesehatan lingkungan yang merupakan bagian penting dari pendidikan Usia Dini dan strategisnya kerjasama dengan masyarakat menjadikan POKJA RA Poncol mengadakan program Gerakan Shedakah Sampah (GESHOSA). Program ini didasarkan kenyataan bahwa permasalahan sampah di Magetan sangat terkait dengan masalah jangkauan pelayanan, dampak dari perilaku pembuangan sampah yang tidak baik, dan masalah teknis pengelolaan sampah, serta kesadaran masyarakat dalam mensikapi dan mengelola sampah.Masyarakat masih banyak yang membuang sampah sembarangan di sungai. Bahkan ketika sudah disediakan tempat pembuangan sampah sememtara (TPSS) di lingkungannya, masyarakat masih tidak tertib dalam waktu ataupun tempat membuang 
sampahnya. Konsep 3R (reduse, replace,recycle) tidak diterapkan dengan baik danperilaku membuang sampah sembarangan masih tinggi (Mulasari, Husodo, \& Muhadjir, 2016, p. 99). Fenomena tersebut menunjukkan betapa rendahnya rasa dan perilaku peduli lingkungan manusia saat ini. Ananda, (2017) menyatakan bahwa melatih anak untuk dapat membedakan sikap dan perilaku yang baik dan yang tidak baik sehingga dengan sadar berusaha menghindarkan diri dari perbuatan tercela sebagai wahana untuk terciptanya situasi belajar anak yang berlangsung tertib, aktif, dan penuh perhatian, melatih anak didik untuk mencintai lingkungan yang bersih dan sehat, dan menanamkan kebiasaan disiplin dalam kehidupan sehari-hari.

Melihat berbagai fenomena di atas, POKJA RA Poncol merasa bertanggung jawab untuk menanamkan rasa peduli, empati, simpati, tanggung jawab, peka sosial dalam menjaga dan memperhatikan lingkungan serta melestarikannya.Terjadinya degradasi lingkungan merupakan bentuk permasalahan yang salah satunya karena permasalahan sampah yang mencerminkan akar dari rendahnya perilaku peduli lingkungan manusia. Maka, diperlukannya wadah dan sistem edukasi yang tepat dalam menanamkan nilai peduli lingkungan demi menjaga lingkungan dan makhluk hidup.

Program Gerakan Sedekah Sampah (GESHOSA) yang dilakukan oleh POKJA RA Poncol merupakan bentuk wadah dan sistem edukasi yang mampu menanamkanpembiasaan positif dalam kehidupan pada anak sejak dini sebagai bentuk nyata berperilaku hidupn sehat dan untuk mengatasi degradasi lingkungan tersebut (Herliyati \& Suparmini, 2018) secara berkesinambungan (sustainable), yang meliputi tahap penyadaran, tahap tranformasi kemampuan, dan tahap peningkatan kemampuan intelektual dan kecakapan-keterampilan. GESHOSA selain sebagai alternatif pendidikan karakter juga sebagai bentuk telah menjadi bagian dari literasi keuangan dalam meningkatkan mutu pendidikan. Selain itu, pengelolaan sampah melalui sedekah sampah ini telah menjadi alternatif pemecahan masalah sampah yangmampu memadukan unsur edukasi dan pemberdayaan, serta telahmenjadi salah satu solusi sumber pembiayaan bagi lembaga pendidikan di POKJA RA Poncol Magetan. Sehingga dapat dikatakan bahwa GESHOSA telah mampu memadukan aspek pendidikan, kesehatan, dan ekonomi. Peneliti berkesimpulan bahwa kegiatan GESHOSA di POKJA RA Poncol bisa menjadi best practice bagi madrasah di Indonesia mulai RA, MI, MTs, MA yang berjumlah sekitar 77.336 buah, dengan jumlah guru sebanyak 820.835 jiwa, dan jumlah siswa sebanyak 9.252.437 anak, khusus RA berjumlah 27.999 buah. ("EMIS | Dashboard | Pendis Kemenag," n.d.)

\section{Kontruksi Mutu melalui Literasi Keuangan}

Mutu difahami sebagai suatu yang memuaskan dan melampaui keinginan dari pelanggan atau sering disebut dengan mutu sesuai persepsi (quality in perseption) (Sallis, 2006, p. 56). Mutu lulusan tercapai diukur dari tingkat ketercapaian lembaga pendidikan dan kurikuler yang ditetapkan sebagai gambaran kualitas akademik pendidikan serta kesesuaian lulusan dengan tuntutan dan kebutuhan seluruh pemangku kepentingan pendidikan (stakeholders) atau masyarakat secara holistik (baik tuntutan masyarakat lokal, regional, maupun masyarakat global).

Edward Sallis mendefiniskan sebagai sebuah konsep yang absolute sekaligus relative. Konsep yang absolut karena mutu menjadi percakapan sehari-hari oleh sebagian besar manusia. Mutu sama halnya dengan sifat baik, cantik, dan benar merupakan suatu hal yang tidak bisa dikompromikan. Dalam definisi yang absulut tersebut, sesuatu yang bermutu merupakan bagian dari standar yang sangat tinggi dan tidak dapat diungguli (Sallis, 2006). Adapun mutu sebagai suatu yang relatif memiliki dua aspek. Pertama, mutu di ukur dan di nilai berdasarkan persyaratan kriteria dan spesifikasi (standar-standar) yang telah ditetapkan lebih dahulu. Kedua, konsep ini mengakomodasi keinginan konsumen atau pelanggan, sebab didalam penetapan standar produk dan atau jasa yang akan dihasilkan 
telah memperhatikan syarat-syarat yang dikehendaki pelanggan bukan semata-mata kehendak produsen (Sallis, 2006). berikut:

Hubungan antara mutu dengan produsen dan konsumen dapat digambarkan sebagai

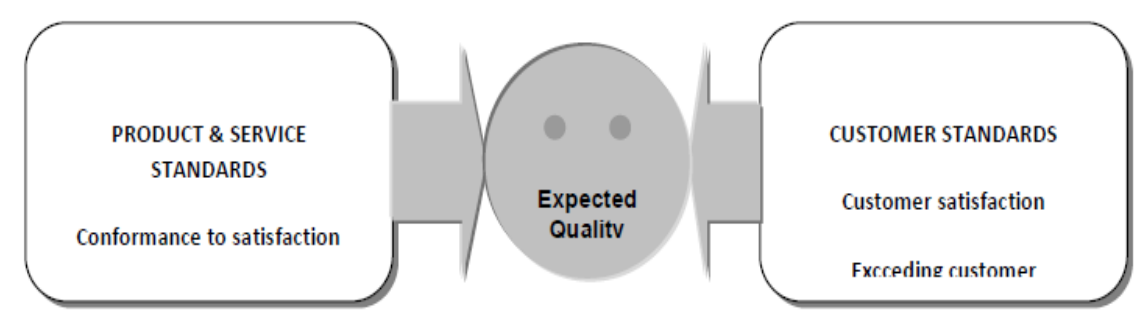

Gambar 1. Hubungan Prose Mutu

Konsep tentang mutu di atas, semua menekankan bahwa kualitas dikaitkan dengan standar produksi dan biaya, artinya produk dinilai berkualitas jika memiliki kesesuaian terhadap spesifikasi dan memenuhi persyaratan biaya. Adapun consumer's perspective, menyatakan kualitas produk dikaitkan dengan desain dan harga. Artinya produk dilihat dari karakteristik kualitas dan harga yang ditentukan. Kualitas suatu produk sangat tergantung antara kesesuaian antara perspektif produsen dengan perspektif konsumen yang disebut dengan kesesuaian untuk digunakan (fitness for consumer use). Dalam konteks ini sangatlah jelas kaitan antara mutu dengan manajemen pembiayaan pendidikan yang mencangkup budgeting, accounting, auditing. Mutu bersifat (mutually beneficial supplier relationship) (Muhaimin, 2005)

Tahun 2018 Kemenag untuk madrasah mengalokasikan dana sebesar Rp 201 miliar dan akan dilanjutkan tahun 2019 sebesar Rp 751 miliar. Dana ini akan terus ditingkatkan hingga sebesar Rp 1 triliun hingga tahun 2020. Jumlah tersebut sangatlah tidak sebanding jumlah madrasah termasuk RA di Indonesia yakni 77.336 buah, yang $92 \%$ adalah berstatus swasta, dana tersebut berarti hanya $10 \%$ dari dana untuk sekolah umum. Besaran anggaran tersebut, bila dibadingkan dengan tuntutan sdandar mutu yang telah ditetapakan oleh pemerintah, dana dari pemerintah relatif sangat kecil danterbatas jumlahnya. Hal ini artinya harus ada pemahaman tanggung jawab tentang mutu pendidikan harus melibatkan masyarakat dan lingkungan sekolah.

Hal ini sejalan dengan pernyataan Zubaidi: "Dari sekian permasalahan yang ada dalam pendidikan Islam, masalah pendanaan dan fasilitas pendidikan menjadi masalah yang krusial", oleh sebab itu, seharusnya ada pergeseran pemahaman bahwa, masalah biaya pendidikan tidak seharusnya menjadi tanggung jawab pemerintah, akan tetapi juga menjadi tanggung jawab masyarakat dan lingkungan sekolah. Maka optimalisasi pembiayaan pendidikan yang bersumber pada lingkungan pendidikan melalui pemberdayaan peran serta masyarakat di dalamnya tidak bisa ditawar-tawar lagi. Sebagaimana disebutkan dalam pedoman Undang-Undang Republik Indonesia Nomor20 Tahun 2003 Tentang Sistem Pendidikan Nasional Pasal 9 bahwa: Masyarakat berkewajiban memberikan dukungan sumber daya dalam penyelenggaraan pendidikan.

UU RI No 20 tahun 2003 tentang Sistem Pendidikan Nasional Bab XV Pasal 54 ayat 1 dan 2, selain memberikan dukungan sumber pembiayaan, masyarakat juga memiliki peran dalam penyelenggaraan pendidikan:

"Peran serta masyarakat dalam pendidikan meliputi peran serta perseorangan, kelompok, keluarga, organisasi profesi, pengusaha dan organisasi kemasyarakatan dalam penyelenggaraan dan pengendalian mutu pelayanan pendidikan. Masyarakat dapat berperan serta sebagai sumber, pelaksana dan pengguna hasil pendidikan". 
Berdasarkan UU tersebut, maka tata kelola keuangan pendidikan harus dilakukan secara transparan dan akuntable, sehingga masyarakat berhak untuk mengetahui prosesproses manajemen pembiayaan pendidikan yang dijalakan oleh sekolah, sehingga pembiayaan yang bersumber dari masyarakat dapat diketahui tingkat efektivitas dan efsiensinya. Sejalan dengan ketentuanperundang-undangan tersebut, sangatlah luas dan terbuka kesempatan bagi masyarakat untuk terlibat dan dilibatkan dalam pengelolaan pendidikan terutama.pendidikan di sekolah swasta termasuk RA, baik dalam aspek pemikiran yang terkait dengan kebijakan RA, maupun peran serta dalam hal fisik material. Oleh karena itu, sangat diperlukan adanya tata kelola pembiayaan yang bersumber dari masyarakat/orang tua siswa secara terbuka dan transparan. Begitu urgennya pembiayaan dalam pendidikan, maka diperlukan serangkaian kegiatan yang terdiri dari perencanaan program sekolah, perkiraan anggaran, pembelanjaan anggaran, pengawasan dan pelaporan pembiayaan yang disebut dengan manajemen pembiayaan pendidikan.

Persoalan lemahnya pengelola pendidikan di tingkat RA dalam hal manajemen pembiayaan pendidikan sebaiknya harus segera dicarikan solusi yang komprehensip, untuk itu memerlukan diadvokasi dan edukasi dari pihak-pihak terkait agar pengelola pendidikan RA memiliki keterampilan bagaimanamenggunakan dan mencari alternatif pembiayaan pendidikannya, sehingga kebutuhan operasionalnya terpenuhi. Ini artinya,literasi keuanganbagi pengelola lembaga menjadi sangat vital, agar kualitas lembaga pendidikannya berjalan dengan baik pada jangka pendek maupun jangka panjang.Tingkat literasi keuangan yang baik, maka setiap individu atau pengelola lembaga pendidikan akan mampu mengambil keputusan yang tepat dalam melakukan perencanaan, pengelolaan, dan evaluasi pembiayaan sekolah, serta mampu untuk melakukan analisis manfaat dan resiko dalam setiap pengambilan keputusan keuangan sekolah

Secara sederhana literasi merupakan proses sosial yang berkaitan dengan literasi kemampuan seseorang dalam menggunakan informasi tertulis ataupun cetak untuk mengembangkan pengetahuan yang bermanfaat bagi masyarakat (Inten, Neneng, Permatasari, 2020: 368). Literasi berfokus pada pembelajaran interaksi antara orang dewasa (apakah orangtua di rumah atau guru di kelas) dan siswa. Sehingga pendidikan literasi keuangan dapat diartikan sebagai sebuah pemahaman yang komprehensif serta mendalam tentang pengelolaan keuangan pribadi, organisasi pendidikan ataupun keluarga yang membuat seseorang mempunyai kuasa, pemahaman dan keyakinan penuh terhadap keputusan keuangan yang diambil.

Literasi keuangan juga menjadi sebuah instrumen dalam memahami kondisi keuangan serta konsep-konsep keuangan secara tepat kedalam perilaku. Konsep keuangan ini meliputi pengetahuan seputar lembaga keuangan beserta produk yang ditawarkan. Tingkat literasi keuanganakan sangat menentukan dalam pengambilan keputusan pembiayaan pendidikan baik pada perencanaan, pengelolaannya dan pelaporannya (Komara, Widyastuti, \& Layyinaturrobaniyah, 2018, p. 2). Dengan demikian, literasi keuangan (financial literacy) atau cerdas finansial, atauy melek keuangan, adalah keadaan dimana seseorang mampu mengelola keuangan yang dapat dapat memberikan nilai tambah secara ekonomis bagi dirinya sendiri maupun bagi lembaga/organisasinya.

Pentingnya pengetahuan yang mendalam tentang literasi keuangan tersebut, menjadi faktor penting bagi pengelola pendidikan untuk memahami dan menyadari bagaimanaa seharusnya pembiayaan pendidikan digali dari sumber-sumber mana, dialokasikan pada program kegiatan yang mendukung standar mutu dan bagaimana melaporkan sesuai dengan prinsip-prinsip manajemen pembiayaan pendidikan.Untuk itu pendidikan literasi keuangan harus diberikan sedini mungkin kepada anak terutama anak pada usia pra sekolah dan sekolah dasar, karena dengan pengenalan terhadap pengetahuan literasi keuangan sejak dini akan membuat anak terbiasa mengelola keuangan dengan baik dan benar dimasa yang akan datang. 
Di Indonesia pendidikan literasi keuangan masih menjadi sesuatu yang sangat jarang dilakukan. Baik di lingkup keluarga ataupun sekolah, pemberian pendidikan tentang literasi keuangan masih belum dilakukan secara serius dan terencana. Dalam budaya masyarakat Indonesia, adalah tabu membicarakan segala sesuatu tentang uang di hadapan anak. Itulah mengapa pengetahuan, sikap, dan ketrampilan tentang kesehatan finansial keluarga tidak mendapat porsi pada kurikulum pendidikan dasar dan menengah, bahkan pada tingkat perguruan tinggi. Oleh karena itu, muncul pandangan bahwa literasi finansial bukan merupakan kecakapan hidup (lifeskills) yang harus dibekalkan kepada peserta didik.

Agar dapat memiliki kesejahteraan finansial yang baik, para pengelola pendidikan di POKJA RA Poncol melalui GESHOSA telah memahami bagaimana menggunakan pendapatannya agar kebutuhan selama dalam jangan tertentu terpenuhi, yang pada akhirnya para para pengelola pendidikan dapat mengelola keuangannya dengan lebih optimal, sehinggatelah terjadi jaminan kualitas pendidikannya baik pada aspek dari perencanaan, pelaksanaan dan evaluasinya. Artinya keterampilan literasi keuangan sudah harus menjadi life skill. Program GESHOSA tersebut, telah sejalan dengan kebijakan otonomi daerah dan desentraslisi pendidikan, yang menyerahkan masalah pendidikan ke daerah dan sekolah masing-masing.Otonomi daerah menimbulkan adanya Manajemen Berbasis Sekolah (MBS) yang perlu diterapkan disetiap satuan pendidikan sekolah. MBS merupakan paradigma baru manajemen pendidikan yang memberikan otonomi luas pada sekolah, dan melibatkan masyarakat dalam kerangka kebijakan pendidikan nasional (Mukhibat, 2013). Otonomi diberikan agar sekolah leluasa mengelola sumber daya, sumber dana, sumber balajar dan mengalokasikannya sesuai prioritas kebutuhan sekolah.

Dengan demikian kemampuan literasi keuangan telah menjadi sangat penting bagi pengelola RA dalam menyusun laporan arus kas sebagai implementasi dari RAPBS yang telah disusun dan diimplementasikan.Laporan arus kas sendiri adalah sebuah laporan yang menunjukkan perincian dari arus kas masuk (penerimaan) dan keluar (pengeluaran) suatu perusahaan pada suatu periode tertentu. Yang biasa digambarkan dalam laporan keuangan arus kas (cash flow statement) meliputi jumlah kas yang diterima, seperti pendapatan tunai dan investasi tunai dari pemilik, serta jumlah kas yang dikeluarkan perusahaan, seperti beban-beban yang harus dikeluarkan, pembayaran utang, dan pengambilan prive.

Adapun RAPBS sebagaimana diketahui adalah adalah rencana biaya dan pendanaan rinci untuk tahun pertama dan merupakan dokumen anggaran sekolah resmi yang harus ditandatangani oleh Komite Sekolah dan Kepala Sekolah serta penanggungjawab perumusan RAPBS, untuk menjadi anggaran Pendapatan dan Belanja Sekolah.Anggaran bagi pengelola RA di POKJA RA Poncol memiliki peran penting dalam konstruksi mutu mulai dari perencanaan, pengendalian, dan evaluasi aktivitas yang dilakukan oleh sekolah/madrasah. Untuk itu, setiap penanggung jawab program telah menjalankan aktivitas sesuai dengan anggaran yang telah ditentukan sebelumnya, yang menurut Muhamin (Muhaimin, 2015, p. 357), ada tiga bagian penting yang harus difahami oleh sekolah dalam penyusunan anggaran, yaitu: 1) Target penerimaan, 2) Rencana pengeluaran, 3) Sumber dana lainnya, yaitu sisa dana periode sebelumnya yang menjadi saldo awal periode berjalan.

RAPBS di POKJA RA Poncol dibuat untuk satu tahun anggaran pelajaran mendatang bisa tertata dengan baik, karena telah bisa mencakup semua biaya dan pendapatan yang ada pada Rencana Anggaran Pendapatan dan Biaya Tahunan, khususnya untuk tahun anggaran mendatang. Pendapatan yang dicantumkan di RAPBS mencakup dana dalam bentuk uang, baik yang akan diterima dan dikelola langsung oleh sekolah yang salah satu sumbernya adalah dari program sedekah sampah. RAPBS di POKJA RA Poncol disusun dengan langkah-langkah: 1) Inventarisasi kegiatan untuk tahun yang akan datang, baik kegiatan rutin maupun kegiatan pembangunan/ pengembangan berdasarkan evaluasi pelaksanaan kegiatan pada tahun sebelumnya, analisis kebutuhan tahun berikutnya, dan masukan dari 
seluruh warga sekolah maupun Komite sekolah. 2) Inventarisasi sumber pembiayaan baik dari rutin maupun pengembangan.3) Penyusunan Rencana Kegiatan sekolah (RKS) yang lengkap berdasarkan Langkah poin (1) dan (2). Kepala sekolah membuat tabel RKS yang terdiri dari kolom-kolom nomor urut, uraian kegiatan, sasaran, kolom-kolom perincian dana dari berbagai sumber, dan kolom jumlah. Tabel tersebut diisi sesuai kolom yang ada. 4) Penyusunan RAPBS, Kepala sekolah membuat tabel RAPBS yang terdiri dari kolom-kolom, yaitu kolom rencana penerimaan dan jumlahnya, kolom rencana pengeluaran dan jumlahnya. Tabel tersebut diisi kemudian ditandatangani oleh Kepala sekolah dan Ketua komite sekolah dan diketahui oleh Kepala Dinas Pendidikan setempat.

Laporan arus kas telah yang merupakan bagian dari pelaksanaan RAPBS telah membantu RA untuk mengetahui tindakan yang sebaiknya ditempuh untuk memaksimalkan out put dan out come nya, maka laporan arus kas telah dibentuk dengan benar dan tepat dan bermanfaat bagi informasi mengenai kemampuan entitas RA dalam menghasilkan arus kas di masa depan dan juga bisa mengetahui besarnya kemampuan RA dalam membayar dividen dan memenuhi kewajibannya (seperti membayar gaji guru).

\section{SIMPULAN}

Program sedekah sampah di POKJA RA Poncol telah memiliki kinerja yang baik karena mampu menghasilkan perubahan positif bagi warga sekolah di POKJA RA Poncol, baik fisik maupun non fisik Perubahan tersebut meliputi perubahan pola pikir masyarakat terhadap program dan kegiatan dalam bidang pendidikan, kesehatan, ekonomi dan lingkungan. Pengetahuan warga sekolah di POKJA RA Poncol tentang sampah dan permasalahannya, jenis-jenis sampah, dan pengelolaan sampah berdasar partisipasi masyarakat telah meningkat rata-rata $80 \%$ setelah mengikuti serangkaian kegiatan sosisialisasi dan pelatihan tentang pengelolaan sampah dengan reduse, replace,recycle. POKJA RA Poncol Magetan telah memiliki keterampilan dalam menyusun arus kas yang benar, serta memiliki kesiapan yang optimal dalam aspek perencanaan, pelaksanaan, dan evaluasi pembelajaranmelalui sedekah sampah, dimana sedekah sampah merupakan alternatif pemecahan masalah sampah yang memadukan unsur edukasi dan pemberdayaan yang berkelanjutan dalam meningkatkan mutu pendidikan.

\section{UCAPAN TERIMAKASIH}

Terima kasih kepada Diktis Kemenag RI yang telah mendanai kegiatan penelitian ini dan warga RA POKJA RA Poncol yang telah memberi persetujuan dan membantu peneliti selama proses pengumpulan data. Ucapan terima kasih juga disampaikan kepada tim editor Jurnal Obsesi yang telah memberikan saran, kritik, dan rekomendasi untuk perbaikan artikel ini.

\section{DAFTAR PUSTAKA}

Ananda, R. (2017). Implementasi Nilai-nilai Moral dan Agama pada Anak Usia Dini. Jurnal Obsesi : Jurnal Pendidikan Anak Usia Dini, 1(1), 19-31. https://doi.org/10.31004/obsesi.v1i1.28

EMIS | Dashboard | Pendis Kemenag. (n.d.). Retrieved January 17, 2020, from http://emispendis.kemenag.go.id/dashboard/?content=data-statistik

Firdaus, R., \& Ariyanti, M. (2004). Manajemen Perkreditan Bank umum (Teori, Masalah, Kebijakan dan Aplikasinya Lengkap dengan Analisa Kredit). Bandung: Alfa Beta.

Herliyati, C. P., \& Suparmini, S. (2018). Perilaku Peduli Lingkungan Siswa dan Pelaksanaan Program Sedekah Sampah di Smpit Ar Raihan Bantul. Social Studies, 7(5), 497-506.

Indonesia, R. (2003). Undang Undang Nomor 20 Tahun 2003 tentang Sistem Pendidikan Nasional. Jakarta.

Komara, R., Widyastuti, A., \& Layyinaturrobaniyah, L. (2018). Kemandirian Aparatur Sipil 
DOI: $10.31004 /$ obsesi.v4i2.412

Negara (ASN) Melalui Literasi Keuangan. Proceeding of Community Development, 1, 1. https://doi.org/10.30874/comdev.2017.1

Magetan, K. A. Data. , (2019).

Maya, S., Haryono, S., \& Kholisya, U. (2018). Pemberdayaan Masyarakat Melalui Pengelolaan Sampah Menjadi Nilai Ekonomis dan Pembentukan Bank Sampah di Kelurahan Tanjung Barat. Proceeding of Community Development, 1, 157. https://doi.org/10.30874/comdev.2017.21

Muhaimin. (2005). Mutu di Universitas Islam Malang. Malang: Kantor Jaminan Mutu UIN Malang.

Muhaimin. (2015). Manajemen Pendidikan: Aplikasinya dalam Penyusunan Rencana Pengembangan Sekolah/Madrasah. Jakarta: Prenada Media Group.

Mukhibat. (2013). Manajemen Berbasis Madrasah, Praktik dan Riset Pendidikan. Yogyakarta: Pustaka Felicha.

Mulasari, S. A., Husodo, A. H., \& Muhadjir, N. (2016). Analisis Situasi Permasalahan Sampah Kota Yogyakarta dan Kebijakan Penanggulangannya. Jurnal Kesehatan Masyarakat, 11(2), 259. https://doi.org/10.15294/kemas.v11i2.3989

Rindaningsih, I. (2012). Pengembangan Model Manajemen Strategik Berbasis (beyond center and circle Time) BCCT Pada PAUD. PEDAGOGIA: Jurnal Pendidikan, 1(2), 213. https://doi.org/10.21070/pedagogia.v1i2.42

Rosyidah, A. N., Sudarmin, S. S., \& Siadi, K. K. (2013). Pengembangan Modul IPA Berbasis Etnosains Zat Aditif dalam Bahan Makanan untuk Kelas VIII SMP Negeri 1 Pegandon Kendal. Unnes Science Education Journal, 2(1).

Sallis, E. (2006). Total Quality Management in Education. Jogjakarta: IRCiSoD.

Sonedi, S., Jamalie, Z., \& Majeri, M. (2017). Manajemen Pembiayaan Pendidikan Bersumber dari Masyarakat. FENOMENA, 9(1), 25. https://doi.org/10.21093/fj.v9i1.702

Triwardani, R. (2013). Pembudayaan Karakter Peduli Lingkungan Melalui Kegiatan Bank Sampah Di Desa Duwet Kecamatan Bendo Kabupaten Magetan. Kajian Moral Dan Kewarganegaraan, 3(1), 470-484. 